\title{
Economic Viability of Conventional Sprinkler Irrigation in Sudan Grass Production for Beef Cattle
}

Wellington Mezzomo (Corresponding Author), Marcia Xavier Peiter, Adroaldo Dias Robaina, Anderson Crestani Pereira, Jhosefe Brunning, Miguel Chaiben Neto, Ricardo Boscaini, Luis Humberto Bahú Ben

Dept. of rural engineering, Federal University of Santa Maria, Av. Roraima, 1000 Camobi, Santa Maria - RS, Brazil

Tel: (55) 98148-3730 (Corresponding Author). E-mail: wellingtonmezzomo@gmail.com; mpeiter@gmail.com; diasrobaina@gmail.com; acrestanipereira@gmail.com; jhosefe.b@gmail.com; miguelchaiben@gmail.com; ricardoboscaini75@gmail.com; luishumbertoben@gmail.com

Jardel Henrique Kirchner, Bruna Dalcin Pimenta

Professor of Basic Technical and Technological Education at the Federal Institute of Education, Science and Technology of Rio Grande do Sul Nelsi Ribas Fritsch, 1111 - Esperança, Ibirubá - RS, Brazil

E-mail: jardel.kirchner@ibiruba.ifrs.edu.br; bruna.pimenta@ibiruba.ifrs.edu.br

\section{Rogério Ricalde Torres}

Professor of Basic Technical and Technological Education at the Federal Institute of Education, Science and Technology of Rio Grande do Sul Eng. João Viterbo de Oliveira, 3061 - Vacaria - RS, Brazil

E-mail: rogerio.torres@vacaria.ifrs.edu.br

\section{Ricardo Benetti Rosso}

Professor of Federal Institute of Santa Catarina

Highway SC 283, no number, Fragosos - Concórdia - SC, Brazil

E-mail: ricardo.rosso@ifc.edu.br

Received: Feb. 27, 2020

doi:10.5296/jas.v8i2.16569
Accepted: Apr. 27, $2020 \quad$ Published: May 13, 2020

URL: https://doi.org/10.5296/jas.v8i2.16569 


\section{Abstract}

The supplementary irrigation is an alternative to ensure forage production and quality in periods with irregular rainfall, however, is necessary to know the irrigation economic viability in order to maximize profits. The study was performed in Santa Maria, Rio Grande do Sul State in southern Brazil, during 2015/2016 and 2016/2017 agricultural years, aiming to evaluate the sudan grass economic viability under different irrigation depths, in order to define which irrigation depth $(0,25,50,75,100$ and $125 \%$ of the reference evapotranspiration-ETo) has the highest net revenue. Forage production functions were generated and allowed to establish the carrying capacity and production costs related to each applied irrigation depth. The forage supply was $4 \%$ of the liveweight, animals with $300 \mathrm{~kg}$ were considered, and average daily liveweight (LW) gains of $0.5,1.0$ and $1.5 \mathrm{~kg} \mathrm{LW} \mathrm{day}^{-1}$ were simulated for the conversion of dry mass production in liveweight gain per hectare. Gross revenue was determined considering the price of $\mathrm{R} \$ 6.50$ per kilogram of liveweight. The production costs were divided into fixed and variable, related and not related to irrigation. The conventional sprinkler irrigation was economically viable for the sudan grass cultivation for beef cattle production, with the highest net revenue for the irrigation depth of $100 \%$ of ETo, in both years. However, the animals feed conversion is the determinant factor in net revenue because it represents the greatest profits variation source.

Keywords: carrying capacity, feed conversion, net revenue

\section{Introduction}

Cultivated, natural and native pastures cover, approximately, 162 million hectares in Brazil. Approximately $68 \%$ of this total area is under cultivated pastures (ABIEC, 2019; IBGE, 2017), which represents the most viable and practical way for cattle feed (Kirchner et al., 2019a).

Among the current options for cultivated pastures, sudan grass (Sorghum sudanense (Piper) Stapf) has been highlighting due to its characteristics, such as high forage production, great leaf-to-stem (L/S) ratios, early sowing possibility, long production cycle, high tillering, rusticity regarding the low soil nutritional conditions and great pasture management flexibility (EMBRAPA, 2014). Water requirement during sudan grass plants proper development varies from $350 \mathrm{~mm}$ up to $700 \mathrm{~mm}$, depending on weather conditions, management and cycle length (Silveira et al., 2015).

Economic benefits provided by the sudan grass, cultivar BRS Estribo, were highlighted in a study performed by EMBRAPA (2018), which has been promising, mainly in the southernmost Brazilian region. The economic impact in 2018 was estimated at R \$ 172 million, provided by both beef cattle productivity increase, decrease in forage costs for feed dairy cattle and selling seeds.

The highest climatic instability during the crop cycle (spring-summer seasons) is characteristic of the large part of Brazil. As a consequence, spatial and temporal rainfall distribution is irregular or occurs rainfall scarcity. The supplementary irrigation is an alternative for water supply for crop demand, in order to the maintenance of high and stable 
crop yield throughout the production cycle (Silva et al., 2015). During the cultivation period, sudan grass evapotranspirative demand often is high than the accumulated rainfall, which can compromise the development, yield and, dry matter accumulation.

Irrigation also contributes to increasing forage quality and availability, which provides the increase in beef-cattle production profitability, through weight gain and the reduction of days to slaughter, reflecting on the meat final quality (Soares et al., 2015).

However, irrigation needs to be performed in pasture areas with equipment that facilitates animal management and movement, considering both operational performance and economic viability. Conventional sprinkler irrigation systems are the most appropriate for small farms with low technological level compared to other systems, due to the better use of the farm area, lower cost for irrigation system acquisition and installation, land systematization is not required, and the system operation, management, and maintenance is easy (Mendonça et al., 2007).

Even the benefits of conventional sprinkler irrigation systems, economic results of the adopted techniques are often not evaluated by farmers (Paredes et al., 2014), which commonly use an excessive amount of water for irrigation in order to obtain to ensure high yield. However, this practice results in losses or in low economic returns (Zhang et al., 2017).

Total benefits of irrigation must be higher than the total costs to justify economically an irrigation project (Silva et al., 2013). Thus, irrigation must increase productivity, decrease costs, improve the efficiency of water and energy use, maintain soil moisture favorable to the proper crops development, and improve physical, chemical and biological soil quality (Ayas et al., 2011).

Economic evaluation studies, which considerate the crop yields response under different irrigation depths are essential to turn viable and spread the exploitation of some crop in a region (Bernardo et al., 2008).

The use of irrigation aiming to profit maximization may imply the application of irrigation depths small than full irrigation, even under productivity reduction, as long the significant economic advantage occurs (Lima Junior et al., 2014).

The use of conventional sprinkler irrigation in pastures for finishing cattle is feasible, however, the obtaining of high production is needed to compensate costs provided by the irrigation technology use (Soares et al., 2015). Furthermore, economic evaluation is essential to assess the sustainability of farms that use irrigation in pastures, considering that irrigation is essential for livestock production intensification (Soares et al., 2015).

The financial analysis must be performed considering the production costs, and the gross and net revenues, in order to contribute in the decision-making for the investment, which is indispensable to the efficiency of irrigation projects implementation (Almeida et al., 2018).

The sudan grass seeds cultivar (BRS Estribo) were firstly certified in 2013. Furthermore, the information related to the sudan grass response to irrigation is scarce and contradictory, and there are no studies regarding the technical-economic viability of irrigation of this forage for 
beef cattle production. Thus, the productive and economic standards information for the crop clearly, reliably and objectively are necessary.

In this context, we aimed with this study to determine the technical-economic viability of sudan grass (BRS Estribo) under conventional sprinkler irrigation for beef cattle, in order to contribute to make-decision by farmers based on forage performance and on cattle feed conversion.

\section{Material and Methods}

The economic viability analysis for the production of irrigated sudan grass was carried out comparing net profit, with and without the use of conventional sprinkler irrigation, in two agricultural years, namely 2015/2016 (Year 1) and 2016/2017 (Year 2).

The experiments were carried out at the experimental area of the Colégio Politécnico (Polytechnic School) of Federal University of Santa Maria, in a field cropped by sudan grass, cultivar BRS Estribo. The total forage production was converted into the liveweight gain of beef cattle. Irrigation costs were calculated based on the sudan grass water demand for each year.

\subsection{Experimental Area Characterization}

The climate of the region is humid subtropical without dry season (Cfa), according to the Köppen climate classification (Wollmann and Galvani, 2012). The soil of the experimental area is classified as Argissolo Amarelo Eutrófico típico according to Brazilian Soil Classification System (Santos et al., 2018), and as Acrisol in the IUSS Working Group WRB (IUSS, 2015). The physic-hydric soil properties were determined following the methodology proposed by EMBRAPA (2011). The total soil water retention capacity from the surface up to $50 \mathrm{~cm}$ soil depth was $83.3 \mathrm{~mm}$. The basic infiltration rate, determined by ring infiltrometer methodology, was $15 \mathrm{~mm} \mathrm{~h}^{-1}$.

\subsection{Irrigation System and Management Characterization}

The conventional sprinkler irrigation system used was composed of 24 fixed lateral lines with $24 \mathrm{~m}$ each, connected in a $100 \mathrm{~m}$ main line, with Polyvinyl Chloride (PVC) pipes. Spacing between lateral lines and sprinklers was $4 \mathrm{~m} \mathrm{x} 4 \mathrm{~m}$. Sprinklers (AgroJet, model P5 ${ }^{1 / 2}$ ) were installed at $1.5 \mathrm{~m}$ from the soil surface.

Irrigation were performed whenever the effective rainfall was lower than the crop water demand in the period, considering a fixed 7-day irrigation cycle. Effective rainfall was determined according to the methodology proposed by Millar (1978), where 70\% of rainfall corresponds to effective rainfall, which implies that $30 \%$ of total rainfall was turned in runoff.

The treatments consisted of the application of five different irrigation depths, namely $25 \%$, $50 \%, 75 \%, 100 \%$, and $125 \%$ of the reference evapotranspiration (ETo). The ETo was determined by the Penman-Monteith/FAO equation (Allen et al., 2006), using the meteorological parameters dataset from an automatic meteorological station affiliated at the Brazilian National Institute of Meteorology (Instituto Nacional de Meteorologia-INMET), located at $1500 \mathrm{~m}$ from the experimental area. 
Irrigation depths differentiation was performed according to each pre-established treatment (\% ETo), by varying the opening time of the valves, located at the beginning of each lateral line. Irrigation depths were calibrated by the Christiansen uniformity coefficient (CUC). The CUC had $83 \%$ of uniformity under the $12.2 \mathrm{~mm} \mathrm{~h}^{-1}$ water application rate, which is lower than the soil basic infiltration rate $\left(15 \mathrm{~mm} \mathrm{~h}^{-1}\right)$.

\subsection{Sudan Grass Management}

Sudan grass sowing was performed on November 24, 2015 and on November 29, 2016, under the no-tillage system. The sowing density was 25 seeds per linear meter, spaced $0.36 \mathrm{~m}$ between rows.

Fertilizer application was performed in the sowing line, with fertilizer levels to reach the forage yield expected of $20000 \mathrm{~kg} \mathrm{ha}^{-1}$ dry mass, as recommended by CQFS RS/SC (2016). Therefore, fertilizing was performed by application of $850 \mathrm{~kg} \mathrm{ha}^{-1}$ of mineral fertilizer with a commercial formulation of NPK 5-20-20, nitrogen $(\mathrm{N})$ phosphorus $\left(\mathrm{P}_{2} \mathrm{O}_{5}\right)$ and potassium $\left(\mathrm{K}_{2} \mathrm{O}\right)$, respectively, incorporated at the soil.

Supplementary nitrogen was fractioned during the sudan grass cycle, and applied on the soil surface, without incorporation. The first nitrogen application was performed at the tillering beginning at 25 days after sowing (DAS). The following nitrogen applications were performed after each harvest, at 50 and 80 DAS, respectively. The soil organic matter content, evaluated by the chemical analysis, was considered to determine the nitrogen amount required. The $160 \mathrm{~kg} \mathrm{ha}^{-1}$ of urea was applied at each season, totalizing $480 \mathrm{~kg} \mathrm{ha}^{-1}$ of urea during the whole crop cycle.

The insecticides, fungicides, and herbicides were homogeneously applied throughout the experimental area, preventively or when the first symptoms were observed.

Forage production was evaluated in three samples collected in 0.5 linear meters of plant per plot, taken at $0.15 \mathrm{~m}$ from the surface soil, which totaling 72 samples in each season of standardization harvest (50,80 and 110 DAS).

After samplings, the dry mass (DM) was determined at the laboratory. Plants were separated in two fractions (leaf and stem) and subsequently dried at $65^{\circ} \mathrm{C}$ until constant weight, in a forced-air oven. Finally, each dry mass fraction $\left(\mathrm{kg} \mathrm{ha}^{-1}\right)$ was quantified on a precision scale, and then composed the final sample.

\subsection{Statistical Analysis}

The results were statistically compared by analysis of variance, at $5 \%$ probability of error, and when means were significantly different, the results were subjected to regression analysis. Statistical analyses were performed using the Exp des R package (Ferreira et al., 2014), available in the $\mathrm{R}$ environment (R Core Team, 2018).

\subsection{Animal Liveweight Gain Estimate}

Animal carrying capacity, the maximum of animals to possible be fed per hectare, was calculated considering the sudan grass dry mass production in each year, using the following 
equation (Trindade Júnior et al., 2015):

$$
\mathrm{CC}=\mathrm{FP} / \mathrm{GP} . \mathrm{FS}
$$

$\mathrm{CC}$ : animal carrying capacity ( $\mathrm{kg}$ of $\left.\mathrm{LW} \mathrm{ha} \mathrm{h}^{-1}\right)$; FP: forage productivity ( $\mathrm{kg} \mathrm{DM} \mathrm{ha} \mathrm{Dm}^{-1}$ ); GP: Grazing period (days); FS: forage supply (kg DM day $\left.{ }^{-1} \mathrm{~kg}^{-1} \mathrm{LW}\right)$.

The grazing period (GP) used was 60 days, because this is the interval between the recommended period for grazing beginning and the last performed harvest. The forage supply (FS) used was 4\% (4 kg DM $100 \mathrm{~kg}^{-1} \mathrm{LW}$ ).

Three scenarios of average daily liveweight gain (DLWG) were stablished considering the animal carrying capacity (CC), namely, $0.5,1.0$ and $1.5 \mathrm{~kg} \mathrm{LW} \mathrm{day}{ }^{-1}$, due to the range of normal daily liveweight gain is a function of different dietary conversions (Glienke, 2012).

The initial liveweight (LW) used for simulation was $300 \mathrm{~kg}$ animal ${ }^{-1}$, following the methodology described by Kirchner et al. (2019a). This liveweight is considered the average liveweight at the initial weight gain period (Kirchner et al., 2019a). The liveweight gain (LWG) was determined using the following equation:

$$
\mathrm{LWG}=(\mathrm{CC} / \mathrm{LW}) . \mathrm{DLWG} . \mathrm{GP}
$$

LWG: liveweight gain ( $\mathrm{kg} \mathrm{LW} \mathrm{ha-1);} \mathrm{LW:} \mathrm{animal} \mathrm{weight} \mathrm{(kg} \mathrm{LW);} \mathrm{DLWG:} \mathrm{average} \mathrm{daily}$ liveweight gain $\left(\mathrm{kg} \mathrm{LW} \mathrm{ha} \mathrm{day}^{-1}\right)$.

\subsection{Gross Revenue Obtaining}

The gross revenues for the different irrigation depths were estimated by the forage production conversion into liveweight gain and then multiplied by the average price.

$$
\text { GR }=\text { LWG. SP }
$$

GR: gross revenue $\left(\mathrm{R} \$ \mathrm{ha}^{-1}\right)$; SP: selling price per liveweight $\left(\mathrm{R} \$ \mathrm{LW} \mathrm{kg}{ }^{-1}\right)$.

The average LW selling price of $\mathrm{R} \$ 6.50 \mathrm{~kg}^{-1}$ was considered, according to average values observed in the region during 2019.

\subsection{Forage Production Costs and Economic Return}

Forage production costs were determined in four categories, used by Frizzone and Andrade Júnior (2005) and by Santos Júnior et al. (2014), namely fixed and variable costs, related and unrelated to irrigation, considering the net benefit for the irrigant.

The costs related to irrigation (CRI) were divided into fixed costs (FCRI) and variable costs (VCRI) of irrigation. These costs were determined considering a conventional sprinkler irrigation system project, according to the methodology proposed by Biscaro (2009).

For the conventional sprinkler irrigation system design, the following aspects were kept fixed: $5 \mathrm{~m}$ suction geometric height, $15 \mathrm{~m}$ discharge geometric height, $2 \mathrm{~m}$ slope of the mainline and lateral lines, $2 \mathrm{~m}$ sprinkler head height, $12 \mathrm{~m}$ sprinkler spacing, $100 \mathrm{~m}$ discharge pipe length, and $10 \mathrm{~m}$ suction pipe length. For the same sector, only one commercial pipe diameter 
was selected. The control of the lateral lines in operation was through ball valves.

Component prices were obtained from existing equipment in the region, namely blue PVC pipes (for irrigation), with commercial diameters and the most efficient nominal pressure for each sector (lateral lines, mainline, discharge, and suction lines). The total project cost for one hectare was $\mathrm{R} \$ 7278.25$.

Fixed costs not related to irrigation (FCNRI) were determined considering all necessary operations and inputs (number of man-hours, number of machine-hours, depreciation, soil tillage, fertilizing, seeds, herbicides, fungicides, insecticides), following the methodology proposed by CONAB (2010).

Fixed cost related to irrigation (FCRI) was calculated using the following equation proposed by CONAB (2010):

$$
\mathrm{FCRI}=\mathrm{DC}+\mathrm{CI}+\mathrm{IC}
$$

FCRI: fixed cost related to irrigation $\left(\mathrm{R} \$ \mathrm{ha}^{-1}\right)$; $\mathrm{DC}$ : depreciation cost of the components of the irrigation system $\left(\mathrm{R} \$ \mathrm{ha}^{-1}\right)$; $\mathrm{CI}$ : cost interest on the invested capital $\left(\mathrm{R} \$ \mathrm{ha}^{-1}\right)$; IC: insurance cost of components of the irrigation system $\left(\mathrm{R} \$ \mathrm{ha}^{-1}\right)$.

Depreciation cost of the components of the irrigation system (DC) was calculated by the following equation (CONAB, 2010):

$$
\mathrm{DC}=[(\mathrm{VN}-\mathrm{RV}) / \mathrm{SLh}] . \mathrm{THWh}
$$

$\mathrm{VN}$ : purchase value of the new component $\left(\mathrm{R} \$ \mathrm{ha}^{-1}\right)$; RV: residual value of the component $\left(\mathrm{R} \$ \mathrm{ha}^{-1}\right)$; SLh: service life of the component (h); THWh: total hours worked by component (h).

The cost interest on the invested capital (CI) was determined considering $6.0 \%$ remuneration rate per year on the average value of the equipment, following the same methodology used for the other variables, as follows:

$$
\mathrm{CI}=\{[((\mathrm{VN} . \mathrm{QM}) / 2) / \mathrm{WC}] . \mathrm{THWh}\} . \mathrm{J}
$$

QM: material quantity; WC: material working capacity (h); J: return rate

Residual value (RV) was calculated as $20 \%$ of the purchase value of the new component, considering the service life of 20 years. Insurance cost of components of the irrigation system (IC) was $0.35 \%$ of the purchase value of the new component (VN) (CONAB, 2010), as follows:

$$
\mathrm{IC}=(\mathrm{VN} / 2) \cdot 0.35 .(\mathrm{THWh} / \mathrm{SLh})
$$

VN: purchase value of the new component $\left(\mathrm{R} \$ \mathrm{ha}^{-1}\right)$; SLh: service life of the component $(\mathrm{h})$; THWh: total hours worked by component (h).

Variable costs of irrigation (VCRI) were determined by the sum of the variable costs of electric energy for water depth application, labor used in irrigation and system maintenance: 


$$
\mathrm{VCRI}=\mathrm{VCE}+\mathrm{VCL}+\mathrm{VCEM}
$$

VCRI: variable costs related to irrigation (R\$); VCE: variable cost of electricity (R\$); VCL: variable cost of labor used in irrigation (R\$); VCEM: variable cost of equipment maintenance $(\mathrm{R} \$)$.

Variable cost of electric energy (VCE) was calculated considering the pump power and the time for water depth application, as follows:

$$
\mathrm{VCE}=\mathrm{Pw} \cdot \mathrm{CE} \cdot \mathrm{t} . \mathrm{ID}
$$

Pw: pump power $\left(\mathrm{Kw} \mathrm{h}{ }^{-1}\right)$; CE: cost of electric energy $\left(\mathrm{R} \$ \mathrm{Kw}^{-1}\right)$; t: time to apply one water millimeter $\left(\mathrm{h} \mathrm{mm}^{-1}\right)$; ID: irrigation depth $\left(\mathrm{mm} \mathrm{ha}^{-1}\right)$.

The CE used was $0.32 \mathrm{R} \$ \mathrm{~kW} \mathrm{~h}^{-1}$, considering the green rate set by National Electricity Agency (Agência Nacional de Energia Elétrica - ANEEL), due to this is the average intermediate value.

The variable cost of labor used in irrigation (VCL) was calculated considering the proposed time of 0.5 hours per hectare in each sector of the system for each performed irrigation (Marouelli and Silva, 2011). The hour worked value was calculated according to the methodology proposed by CONAB (2010), with an hourly value equivalent to the rural minimum wage, according to the following equation:

$$
\mathrm{VCL}=\mathrm{NI} . \mathrm{NS} \cdot 0.5 . \mathrm{MW} / 220
$$

NI: number of irrigations; NS: number of sectors in the irrigation system; MW: rural minimum wage $(\mathrm{R} \$)$.

The irrigation system was composed of six sectors for one hectare. The rural minimum wage value considered was $\mathrm{R} \$ 1175.15$.

The variable cost of equipment maintenance (VCEM) was determined over $1 \%$ of irrigation system value plus $10 \%$ of the CE, following the methodology proposed by CONAB (2010), according to the following equation:

$$
\mathrm{VCEM}=\mathrm{VN} .0 .01 .(\mathrm{CE} / 10)
$$

$\mathrm{VN}$ : purchase value of the new component $\left(\mathrm{R} \$ \mathrm{ha}^{-1}\right)$; $\mathrm{CE}$ : cost of electric energy $\left(\mathrm{R} \$ \mathrm{Kw}^{-1}\right)$.

The net revenue in the different scenarios (irrigated with 25, 50, 75, 100 and 125\% of ETo, and without irrigation) for $0.5,1.0$ and $1.5 \mathrm{~kg} \mathrm{LW} \mathrm{day}^{-1}$ was obtained by the following equation:

$$
\mathrm{NR}=\mathrm{GR}-\mathrm{CNRI}-\mathrm{FCRI}-\mathrm{VCRI}
$$

$\mathrm{NR}$ : net revenue to the irrigating farmer $\left(\mathrm{R} \$ \mathrm{ha}^{-1}\right)$; GR: gross revenue ( $\left.\mathrm{R} \$ \mathrm{ha}^{-1}\right)$; CNRI: costs not related to irrigation ( $\left.\mathrm{R} \$ \mathrm{ha}^{-1}\right)$; FCRI: fixed costs related to irrigation $\left(\mathrm{R} \$ \mathrm{ha}^{-1}\right)$; VCRI: variable costs related to irrigation $\left(\mathrm{R} \$ \mathrm{ha}^{-1}\right)$. 


\section{I Macrothink}

\section{Results and Discussion}

High effective rainfall occurred during the experiment conduction, in Year 1 accumulated effective rainfall was $458.04 \mathrm{~mm}$, and $593.18 \mathrm{~mm}$ in Year 2. However, rainfall distribution in both years was irregular, with drought periods and consequent crop water stress, which requiring supplementary water by irrigation to provide the plants water demand (Table 1).

Table 1. Effective rainfall, irrigation depths and total irrigation depths for the different treatments performed in the 2015/2016 and 2016/2017 agricultural years

\begin{tabular}{|c|c|c|c|}
\hline \multicolumn{4}{|c|}{$2015 / 2016$} \\
\hline Treatment & Effective rainfall & Irrigation depth & $\begin{array}{c}\text { Total irrigation } \\
\text { depth }\end{array}$ \\
\hline (\% of ETo) & $\mathbf{m m}$ & $\mathbf{m m}$ & $\mathbf{m m}$ \\
\hline 125 & \multirow{6}{*}{458.04} & 146.82 & 604.86 \\
\hline 100 & & 117.46 & 575.50 \\
\hline 75 & & 88.09 & 546.13 \\
\hline $\mathbf{5 0}$ & & 58.73 & 516.77 \\
\hline 25 & & 29.36 & 487.40 \\
\hline $\mathbf{0}$ & & 0.00 & 458.04 \\
\hline \multicolumn{4}{|c|}{$2016 / 2017$} \\
\hline Treatment & Effective rainfall & Irrigation depth & $\begin{array}{c}\text { Total irrigation } \\
\text { depth }\end{array}$ \\
\hline (\% of ETo) & $\mathbf{m m}$ & $\mathbf{m m}$ & $\mathbf{m m}$ \\
\hline 125 & \multirow{6}{*}{593.18} & 115.65 & 755.05 \\
\hline 100 & & 92.50 & 685.68 \\
\hline 75 & & 69.37 & 662.55 \\
\hline 50 & & 46.25 & 639.43 \\
\hline 25 & & 23.12 & 616.30 \\
\hline $\mathbf{0}$ & & 0.00 & 593.18 \\
\hline
\end{tabular}

In Year 1, the treatment with irrigation depth of $100 \%$ of ETo was irrigated with $117.46 \mathrm{~mm}$, divided into seven applications. While, in Year 2, an irrigation depth of $92.5 \mathrm{~mm}$ was applied for the same treatment and also divided into seven applications, depending on rainfall distribution and crop water demand in each growing season (Figure 1). 


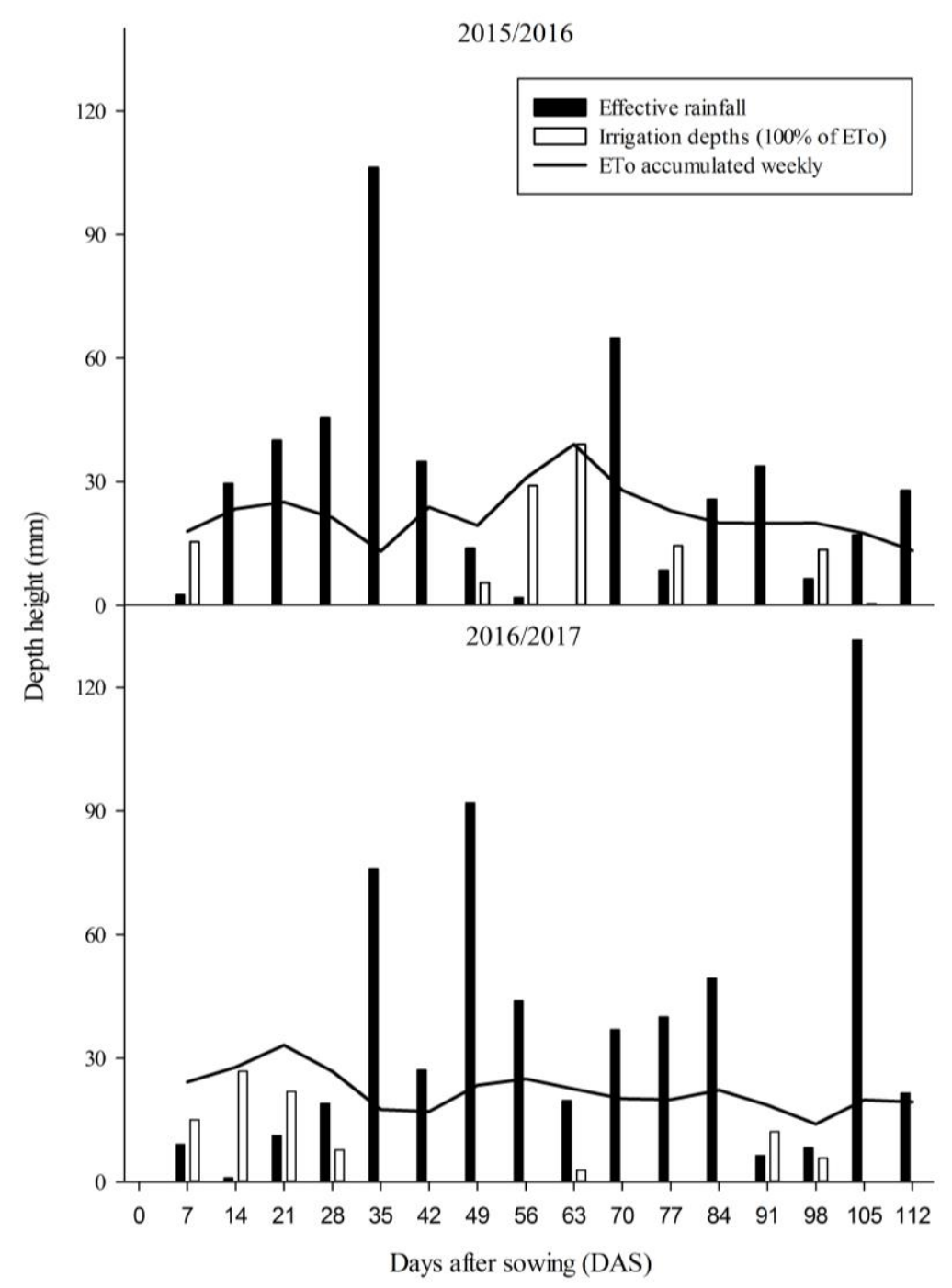

Figure 1. Reference evapotranspiration (ETo), effective rainfall and weekly accumulated irrigation depth during the experiment conduction

Periods of water excess and periods of water stress where the crop evapotranspiration exceeded the rainfall during several weeks occurred over the cycle production (Figure 1). Because this rainfall and evapotranspiration distribution, water stress occurred between sowing and the first harvest in Year 2, implied in need four consecutive irrigations to water supply the crop demand. In Year 1, rainfall distribution exceeded the evapotranspirative demand during the most time of the experiment conduction, where only one irrigation was needed up to 50 DAS.

The not irrigated treatment (control) had high water stress in Year 2 compared to Year 1, mainly in the interval between the sowing and the first harvest. This interval has considerated of the great importance to the forage potential definition, and water stress provides quality, tillering and dry mass production decrease throughout the cycle.

The water stress during the crop initial establishment and tillering leads to a drastic forage 
production decrease, since the main route for nutrient absorption occurs through the mass flow in the soil solution (Reis et al., 2017). Thus, the water stress hinders the absorption and translocation of the nutrients to the growth points, which limits the plant development and tillering, and irrigation is recommended in order to guarantee high production rates and forage quality (Koetz et al., 2017).

The animal liveweight gain per hectare (Table 2) estimated based on the production of DM $\mathrm{ha}^{-1}$, simulate expectations of daily weight gain per animal of $0.5,1.0$ and $1.5 \mathrm{~kg} \mathrm{LW} \mathrm{day}{ }^{-1}$, depending on the bovine breeds genetic diversity and the environmental conditions, which provide different feed conversions. Thus, making it possible to determine the average weight gain per hectare for each scenario, for the respective grazing period.

Table 2. Dry matter production under different irrigation depths converted to carrying capacity per hectare, with the respective liveweight gain simulations for both agricultural years

2015/2016

\begin{tabular}{|c|c|c|c|c|c|c|c|c|c|c|}
\hline Treat. & FP & GP & FS & $\mathbf{A} \mathbf{U}$ & $\mathrm{CC}$ & DM & $\mathbf{N}$ & & $\begin{array}{c}\text { ALWG } \\
\left(\mathrm{kg} \mathrm{ha}^{-1}\right)\end{array}$ & \\
\hline $\begin{array}{c}\% \\
\text { ETo }\end{array}$ & $k g$ ha $^{-1}$ & days & $\%$ & kg & 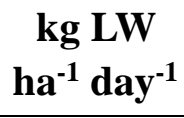 & $\begin{array}{c}\text { kg } \\
\text { day }^{-1}\end{array}$ & unity & 0.5 & 1 & 1.5 \\
\hline 125 & 14079.07 & \multirow{6}{*}{60} & \multirow{6}{*}{4} & \multirow{6}{*}{300} & 5866.28 & 234.65 & 19.55 & 586.63 & 1173.26 & 1759.88 \\
\hline 100 & 14777.98 & & & & 6157.49 & 246.30 & 20.52 & 615.75 & 1231.50 & 1847.25 \\
\hline 75 & 13892.59 & & & & 5788.58 & 231.54 & 19.30 & 578.86 & 1157.72 & 1736.57 \\
\hline 50 & 13057.52 & & & & 5440.63 & 217.63 & 18.14 & 544.06 & 1088.13 & 1632.19 \\
\hline 25 & 11728.26 & & & & 4886.78 & 195.47 & 16.29 & 488.68 & 977.36 & 1466.03 \\
\hline 0 & 10605.78 & & & & 4419.08 & 176.76 & 14.73 & 441.91 & 883.82 & 1325.72 \\
\hline
\end{tabular}

2016/2017

\begin{tabular}{|c|c|c|c|c|c|c|c|c|c|c|}
\hline Treat. & $\mathbf{F P}$ & GP & FS & $\mathbf{A} \mathbf{U}$ & $\mathrm{CC}$ & DM & $\mathbf{N}$ & & $\begin{array}{c}\text { ALWG } \\
\left(\mathrm{kg} \mathrm{ha}^{-1}\right)\end{array}$ & \\
\hline $\begin{array}{c}\% \\
\text { ETo }\end{array}$ & $\operatorname{kg~ha}^{-1}$ & days & $\%$ & kg & $\begin{array}{c}\text { kg LW } \\
\text { ha' }^{-1} \text { day }^{-1}\end{array}$ & $\begin{array}{c}\text { kg } \\
\text { day }^{-1}\end{array}$ & unity & 0.5 & 1 & 1.5 \\
\hline 125 & 13670.69 & \multirow{6}{*}{60} & \multirow{6}{*}{4} & \multirow{6}{*}{300} & 5696.12 & 227.84 & 18.99 & 569.61 & 1139.22 & 1708.84 \\
\hline 100 & 14256.94 & & & & 5940.39 & 237.62 & 19.80 & 594.04 & 1188.08 & 1782.12 \\
\hline 75 & 12999.53 & & & & 5416.47 & 216.66 & 18.05 & 541.65 & 1083.29 & 1624.94 \\
\hline 50 & 11244.32 & & & & 4685.13 & 187.41 & 15.62 & 468.51 & 937.03 & 1405.54 \\
\hline 25 & 9961.20 & & & & 4150.50 & 166.02 & 13.84 & 415.05 & 830.10 & 1245.15 \\
\hline 0 & 8439.53 & & & & 3516.47 & 140.66 & 11.72 & 351.65 & 703.29 & 1054.94 \\
\hline
\end{tabular}


Treat: treatment; FP: forage production; GP: grazing period; FS: forage supply; AU: animal unit; CC: carrying capacity; DM: forage dry mass; N: number of animals per hectare; ALWG: average liveweight gain during the period.

The forage production was statistically different at a 5\% probability of error among the treatments for both two years of study. The sudan grass had forage production functions which resulted in quadratic equations for both years, namely $y=-0.4578 x^{2}+94.363 x+$ 9577.5 for Year 1 and $y=-0.4839 x^{2}+116.88 x+7210$ for Year 2, with coefficients of determination $\left(\mathrm{r}^{2}\right)$ of 0.9658 and 0.9557 , respectively.

The variable y corresponding to the total dry mass of forage production per hectare $(\mathrm{kg}$ DM $\mathrm{ha}^{-1}$ ) obtained from the three harvestings (50, 80 and 110 DAS), and the variable $\mathrm{x}$ corresponding to the irrigation water depth to compensate the evapotranspiration (\% of ETo). The water depths maximum technical efficiency, obtained by these quadratic equations, were $103.1 \%$ and $120.8 \%$ of ETo, respectively for Year 1 and Year 2, with forage yield of 14851.9 $\mathrm{kg} \mathrm{DM} \mathrm{ha}^{-1}$ and $14267.7 \mathrm{~kg} \mathrm{DM} \mathrm{ha}^{-1}$, respectively for Year 1 and Year 2.

Treatments without irrigation were considered as additional controls, due to forage production variation influenced by rainfall in each year. The variation between the two years was $2166.3 \mathrm{~kg} \mathrm{DM} \mathrm{ha}^{-1}$, which represents $20.5 \%$ of the difference in the production.

The dry mass production variation between the control and the treatment with irrigation depth of $100 \%$ of ETo in Year 1 was $3453.29 \mathrm{~kg} \mathrm{DM} \mathrm{ha}^{-1}$, which represents a production increase of $39 \%$. While in Year 2, the difference in production between the same treatments was 5817.41 $\mathrm{kg} \mathrm{DM} \mathrm{ha}{ }^{-1}$, which represents an increase of $68 \%$ when properly irrigated. Although Year 2 had lower total production in all treatments compared to Year 1, the forage production amplitude was greater, due to the plant water stress during the period from sowing up to the 50 DAS.

Dry mass production increased as the irrigation depths increased until treatment with $100 \%$ of ETo in the two years of study. However, treatment with $125 \%$ of ETo lost the potential production, due to the water excess provided by irrigation throughout the crop cycle. This water excess in addition to decrease sudan grass production, also waste energy and water and increased cost production and environmental impact.

The carrying capacity (CC) per hectare varies depending on the dry mass production. The lowest dry mass production and the greatest $\mathrm{CC}$ variation between the two years of study for the treatment without irrigation, which had $902.6 \mathrm{~kg}$ of liveweight difference, equivalent to approximately 3 animals per hectare. While in the treatment with irrigation depth of $100 \%$ of ETo, the variation between the years was only $217 \mathrm{~kg}$ of liveweight, which represents a difference of less than one animal per hectare, confirming the capacity irrigation in keep the production stable over the years.

Highest and lowest carrying capacity per hectare occurred, respectively, in the treatment with irrigation depth of $100 \%$ of ETo and in the control treatment, with a $1447.2 \mathrm{~kg} \mathrm{ha}^{-1}$ of liveweight variation, which corresponds to 4.8 animals, in Year 1. In Year 2, the variation was greater for these treatments, with $2179.7 \mathrm{~kg} \mathrm{ha}^{-1}$ of liveweight, equivalent to 7.3 animals. 


\section{MInstitute ${ }^{\text {Mink }}$}

Journal of Agricultural Studies

ISSN 2166-0379

2020, Vol. 8, No. 2

These differences influenced the average liveweight gain per hectare considering feed conversion of one kilo per day, which ranged between the same treatments in $347.68 \mathrm{~kg} \mathrm{ha}^{-1}$ and $484.78 \mathrm{~kg} \mathrm{ha}^{-1}$, respectively for Year 1 and Year 2.

The performance of bred heifers in millet pastures reached $3119.9 \mathrm{~kg} \mathrm{LW} \mathrm{ha}^{-1}$ in a study performed by Montagner et al. (2008), which is close to the results observed in the control treatment of this study.

The koronivia grass cultivation, in a study performed by Diavão et al. (2017), provided results similar to those obtained in this study, where the carrying capacity was $3080 \mathrm{~kg} \mathrm{LW}$ $\mathrm{ha}^{-1}$, which is close to the $3516 \mathrm{~kg} \mathrm{LW} \mathrm{ha}{ }^{-1}$ observed in the treatment without irrigation in Year 2. The differences in carrying capacity, for both millet and the koronivia grass, were attributed to the greater sudan grass productive potential.

The variable costs of the non-irrigated and irrigated production systems, and the treatments evaluated for the sudan grass cultivation are presented in Table 3.

Table 3. Costs of non-irrigated and irrigated production systems for Year 1 and Year 2 and the irrigation depths evaluated $(25,50,75,100$ and $125 \%$ of ETo)

\begin{tabular}{|c|c|c|c|}
\hline \multicolumn{4}{|c|}{ Production costs } \\
\hline Variable & Trrigation depth (\% ETo) & Year 1 & Year 2 \\
\hline \multicolumn{4}{|c|}{ Fixed costs not related to irrigation (FCNRI) } \\
\hline FCNRI & & 1556.10 & 1638.57 \\
\hline \multicolumn{4}{|c|}{ Fixed costs related to irrigation (FCRI) } \\
\hline DC & All* & 226.85 & 226.85 \\
\hline CI & All* & 170.14 & 170.14 \\
\hline IC & All* & 49.62 & 49.62 \\
\hline FCRI & All* & 446.61 & 446.61 \\
\hline \multicolumn{4}{|c|}{ Variable costs related to irrigation (VCRI) } \\
\hline \multirow{5}{*}{ VCE } & 25 & 22.31 & 17.57 \\
\hline & 50 & 44.61 & 35.13 \\
\hline & 75 & 66.92 & 52.70 \\
\hline & 100 & 89.23 & 70.27 \\
\hline & 125 & 111.53 & 87.83 \\
\hline \multirow[t]{2}{*}{ VCL } & All* & 112.17 & 112.17 \\
\hline & 25 & 20.43 & 19.95 \\
\hline \multirow{4}{*}{ VCEM } & 50 & 40.86 & 39.91 \\
\hline & 75 & 61.28 & 59.86 \\
\hline & 100 & 81.71 & 79.81 \\
\hline & 125 & 102.14 & 99.76 \\
\hline \multirow{5}{*}{ VCRI } & 25 & 154.90 & 149.69 \\
\hline & 50 & 197.64 & 187.21 \\
\hline & 75 & 240.37 & 224.73 \\
\hline & 100 & 283.10 & 262.25 \\
\hline & 125 & 325.84 & 299.77 \\
\hline
\end{tabular}

FCNRI: fixed costs not related to irrigation $\left(\mathrm{R} \$ \mathrm{ha}^{-1}\right)$; FCRI: fixed costs related to irrigation $\left(\mathrm{R} \$ \mathrm{ha}^{-1}\right)$; DC: depreciation cost of the components of the irrigation system $\left(\mathrm{R} \$ \mathrm{ha}^{-1}\right)$; $\mathrm{CI}$ : cost interest on the invested capital $\left(\mathrm{R} \$ \mathrm{ha}^{-1}\right)$; IC: insurance cost of components of the irrigation system ( $\left.\mathrm{R} \$ \mathrm{ha}^{-1}\right)$; VCRI: variable costs related to irrigation $\left(\mathrm{R} \$ \mathrm{ha}^{-1}\right)$; VCE: variable cost of electricity $\left(\mathrm{R} \$ \mathrm{ha}^{-1}\right)$; VCL: variable cost of labor used in irrigation $\left(\mathrm{R} \$ \mathrm{ha}^{-1}\right)$; VCEM: variable cost of equipment maintenance $\left(\mathrm{R} \$ \mathrm{ha}^{-1}\right)$; All*: same variable cost for all irrigation depths.

The FCNRI range from $\mathrm{R} \$ \mathrm{ha}^{-1} 1556.10$ in Year 1 up to $\mathrm{R} \$ \mathrm{ha}^{-1} 1638.57$ in Year 2 due to the 
prices of agricultural inputs variation (herbicides, fungicides, insecticides, seeds, and NPK and urea fertilizers), since cultural management was performed in the same way in both two study years.

The $\mathrm{R} \$ \mathrm{ha}^{-1}$ 446.61 FCRI consists of depreciation cost of the components of the irrigation system, cost interest on the invested capital and insurance cost of components of the irrigation system. The FCRI the same for both years, since its costs are equally distributed over the service life of the components, which was considered as 20 years. The observed FCRI is in agreement with Barbosa (2015), that evaluated the economic viability of conventional irrigation for tomato cultivation and found the FCRI of R $\$ \mathrm{ha}^{-1} 420.37$.

In Year 1, the VCRI range from $\mathrm{R} \$ \mathrm{ha}^{-1} 154.90$ in the treatment subjected to an irrigation depth of $25 \%$ of ETo, up to $\mathrm{R} \$ \mathrm{ha}^{-1} 325.84$ in the treatment subjected to an irrigation depth of $125 \%$ of ETo. While, in Year 2, the VCRI ranged from $\mathrm{R} \$ \mathrm{ha}^{-1} 149.69$ up to $\mathrm{R} \$ \mathrm{ha}^{-1} 299.77$, respectively for the same treatments. This cost is comprised of VCE, VCL and VCEM, where the VCE range depending on the electricity demand to the application of different irrigation depths. The VCL ranges according to the number of performed irrigations, regardless of the amount of water applied in each irrigation, as seven irrigations were performed over the two years of study, the VCL remained constant. The VCEM range according to the electricity cost for each treatment.

The VCRI amplitude in Year 1 was $\mathrm{R} \$ \mathrm{ha}^{-1} 170.94$ between the treatments with irrigation depth of $25 \%$ and of $125 \%$ of ETo, while in Year 2, for the same treatments, the amplitude was $\mathrm{R} \$ \mathrm{ha}^{-1} 150.08$. However, low variation (only $\mathrm{R} \$ \mathrm{ha}^{-1} 20.85$ ) was observed by comparing the treatment with irrigation depth of $100 \%$ of ETo in Year 1 in relation to Year 2, due to the greater water amount applied in Year 1, which generates higher electricity and maintenance costs.

The conventional sprinkler irrigation system introduction in the sudan grass cropping, considering the treatment with the irrigation depth of $100 \%$ of ETo, increased the productive system cost in relation to the non-irrigated treatment in $\mathrm{R} \$ \mathrm{ha}^{-1} 729.71$ for the Year 1 , and $\mathrm{R} \$ \mathrm{ha}^{-1} 708.86$ for the Year 2. The introduction of irrigation represented an increase of production costs in $47 \%$ and $43 \%$, respectively.

The economic viability of sprinkler irrigation for the sugarcane cultivation was determined by Pereira et al. (2015), where the variable cost related to irrigation was $R \$ h^{-1} 311.44$ for the management with irrigation depth of $100 \%$ of ETo. This cost is higher than the cost observed in this study, with $9 \%$ of variation in relation to Year 1 and $16 \%$ for Year 2, due to the greater water volume applied.

The fixed cost related to irrigation determined by Castro Júnior et al. (2015) was $\mathrm{R} \$ \mathrm{ha}^{-1}$ $552.76,19 \%$ higher than the value observed in this study, and was attributed to the service life of the system, considered 15 years, while for this study was considered 20 years. However, the production cost increased by the irrigation introduction was the same as in Year 1 , of $47 \%$, which reinforces the results observed in this study.

The production cost, in a study performed by Torres et al. (2019) for millet cropping, 
increased $39.5 \%$ with the irrigation introduction in relation to the non-irrigated treatment, for the region of Santa Maria-RS in the 2016/2017 agricultural years, which corroborates with this study.

The gross revenue, total cost (the sum of both fixed and variable, related and not related to irrigation costs), net revenue and the cost-benefit ratio of the three different daily liveweight gain scenarios, for each irrigation depth, for the two years of study, considering the average price per kilo of beef cattle liveweight for the study region of $\mathrm{R} \$ 6.50$ are shown in Table 4 .

Table 4. Daily liveweight gain (DLWG), gross revenue (GR), total cost (TC), net revenue $(\mathrm{NR})$ and benefit/cost ratio $(\mathrm{B} / \mathrm{C})$ under different irrigation depths, in the two years of study

\begin{tabular}{|c|c|c|c|c|c|c|c|c|c|}
\hline \multirow{3}{*}{$\begin{array}{c}\% \\
\text { ETo }\end{array}$} & \multirow{3}{*}{$\begin{array}{l}\text { DLWG } \\
\text { kg dia }^{-1}\end{array}$} & \multicolumn{4}{|c|}{$2015 / 2016$} & \multicolumn{4}{|c|}{$2016 / 2017$} \\
\hline & & GR & TC & NR & \multirow{2}{*}{$\mathrm{B} / \mathrm{C}$} & GR & $\mathbf{T C}$ & NR & \multirow[b]{2}{*}{$\mathrm{B} / \mathrm{C}$} \\
\hline & & \multicolumn{3}{|c|}{$\mathbf{R} \$ \mathrm{ha}^{-1}$} & & \multicolumn{3}{|c|}{$\mathbf{R} \$ h^{-1}$} & \\
\hline 0 & \multirow{6}{*}{0.5} & 2651.4 & 1556.1 & 1095.3 & 1.7 & 2109.9 & 1638.6 & 471.3 & 1.3 \\
\hline 25 & & 2932.1 & 2196.5 & 735.6 & 1.3 & 2490.1 & 2267.7 & 222.4 & 1.1 \\
\hline 50 & & 3264.4 & 2221.2 & 1043.1 & 1.5 & 2811.1 & 2281.2 & 529.8 & 1.2 \\
\hline 75 & & 3473.1 & 2246.0 & 1227.2 & 1.5 & 3249.9 & 2294.7 & 955.1 & 1.4 \\
\hline 100 & & 3694.5 & 2270.8 & 1423.7 & 1.6 & 3564.2 & 2308.3 & 1256.0 & 1.5 \\
\hline 125 & & 3519.8 & 2295.5 & 1224.3 & 1.5 & 3417.7 & 2321.8 & 1095.9 & 1.5 \\
\hline $\mathbf{0}$ & \multirow{6}{*}{1} & 5302.9 & 1556.1 & 3746.8 & 3.4 & 4219.8 & 1638.6 & 2581.2 & 2.6 \\
\hline 25 & & 5864.1 & 2196.5 & 3667.6 & 2.7 & 4980.6 & 2267.7 & 2712.9 & 2.2 \\
\hline 50 & & 6528.8 & 2221.2 & 4307.5 & 2.9 & 5622.2 & 2281.2 & 3340.9 & 2.5 \\
\hline 75 & & 6946.3 & 2246.0 & 4700.3 & 3.1 & 6499.8 & 2294.7 & 4205.0 & 2.8 \\
\hline 100 & & 7389.0 & 2270.8 & 5118.2 & 3.3 & 7128.5 & 2308.3 & 4820.2 & 3.1 \\
\hline 125 & & 7039.5 & 2295.5 & 4744.0 & 3.1 & 6835.4 & 2321.8 & 4513.5 & 2.9 \\
\hline $\mathbf{0}$ & \multirow{6}{*}{1.5} & 7954.3 & 1556.1 & 6398.2 & 5.1 & 6329.7 & 1638.6 & 4691.1 & 3.9 \\
\hline 25 & & 8796.2 & 2196.5 & 6599.7 & 4.0 & 7470.9 & 2267.7 & 5203.2 & 3.3 \\
\hline 50 & & 9793.1 & 2221.2 & 7571.9 & 4.4 & 8433.2 & 2281.2 & 6152.0 & 3.7 \\
\hline 75 & & 10419.4 & 2246.0 & 8173.4 & 4.6 & 9749.7 & 2294.7 & 7454.9 & 4.2 \\
\hline 100 & & 11083.5 & 2270.8 & 8812.7 & 4.9 & 10692.7 & 2308.3 & 8384.5 & 4.6 \\
\hline 125 & & 10559.3 & 2295.5 & 8263.8 & 4.6 & 10253.0 & 2321.8 & 7931.2 & 4.4 \\
\hline
\end{tabular}

The feed conversion is a fundamental factor for livestock profitability, providing a wide range of variation in net revenue due to daily liveweight gain (Table 4). The different feed conversions provided a difference in Year 1 for the same treatment (100\% of ETo) of R $\$ \mathrm{ha}^{-1}$ 7388.99 between the average liveweight gain of $0.5 \mathrm{~kg} \mathrm{LW} \mathrm{day}^{-1}$ and $1.5 \mathrm{~kg} \mathrm{LW} \mathrm{day}{ }^{-1}$ scenarios, which represents a profitability increase of 519\%. These values evidencing the use of good feed conversion animals importance, in order to obtain a substantial net revenue increase, mainly in irrigated areas that require a great financial investment.

In both years, for $0.5 \mathrm{~kg} \mathrm{LW} \mathrm{day}{ }^{-1}$ scenario, the treatment with the irrigation depth of $25 \%$ of 
ETo provided a lower net revenue than the control treatment. This lower net revenue was obtained due to the irrigation system costs combined with the low animals feed conversion, which considerably increasing costs without the proportional production increase. This result implies the proper irrigation management is essential to intensify production.

The net revenue provided by the irrigation depth of $100 \%$ of ETo in Year 1 was $36 \%$ higher than in the control treatment, considering the liveweight gain of $1.0 \mathrm{~kg} \mathrm{LW} \mathrm{day}^{-1}$ scenario. While in Year 2, for the same treatments and liveweight gain scenario, net revenue difference between treatments was $86 \%$ higher for the irrigation depth of $100 \%$ of ETo, where this difference between years is attributed to the irregular rainfall distribution occurred during the crop cycle. Once, in Year 2, the control treatment had greater water stress, which compromises its economic return, while the irrigated treatments had lower water stress, greater production, and consequently greater net revenue.

The net revenue ranges $45 \%$ between the years of study for the non-irrigated, due to the rainfall irregularity over time, which leads the livestock production unstable and financially insecure, since the activity planning is susceptible to climatic variations. However, comparing the treatment with the irrigation depth of $100 \%$ of ETo between the two years, net revenue ranged only $6 \%$, ensuring the planning of the farmer irrigator in relation to carrying capacity and net returns, which leads the activity more attractive and profitable, with the possibility steady economic returns over the years.

The irrigation depth of $100 \%$ of ETo was more profitable for the three simulated scenarios, in the two years of study, showing that the crop water demand must be fully supplied in order to obtain the greatest economic return. Even with the increase in total cost, net revenue was higher, due to the forage yield increase that exceeded production costs.

These obtained results are in agreement with those obtained by Torres et al. (2019), which evaluating the irrigation economic return for the millet cropping in the region of Santa Maria-RS and Santiago-RS, at the same period of the Year 1, and considering an expected liveweight gain of $1.0 \mathrm{~kg} \mathrm{LW} \mathrm{day}^{-1}$. Net revenue increased $26 \%$ and $44 \%$ with an irrigation depth of $100 \%$ of ETo compared to non-irrigated treatment in the region of Santa Maria-RS and Santiago-RS, respectively (Torres et al., 2019). The net revenue of $36 \%$ found in this study is intermediate to those increases observed by Torres et al. (2019).

The economic viability of conventional sprinkler irrigation for the forage sorghum for beef cattle, at the same time and place of Year 1 and Year 2, Kirchner et al. (2019a) observed results that are in agreement with those observed in this study, where the irrigation depth of $100 \%$ of ETo was most financially profitable in both years. The net revenue was $23 \%$ in Year 1 and $61 \%$ in Year 2 higher with the irrigation depth of $100 \%$ of ETo in relation to the treatment control, been $\mathrm{R} \$ 4478.96$ in Year 1 and $\mathrm{R} \$ 4350.20$ in Year 2, considering a liveweight gain of $1.0 \mathrm{~kg} \mathrm{LW} \mathrm{day}{ }^{-1}$ and the meat price of $\mathrm{R} \$ 6.00 \mathrm{~kg}^{-1}$ (Kirchner et al., 2019a). This net revenue difference between studies is attributed to the higher sudan grass production and to the meat price of $\mathrm{R} \$ 6.50 \mathrm{~kg}^{-1}$.

The benefit/cost ratios of the production systems were feasible, with the benefits greater than 
the costs for all treatments in both years. In Year 1, the highest benefit/cost ratio was provided by treatment without irrigation (control), with a profit of $\mathrm{R} \$ 3.40$ for each $\mathrm{R} \$ 1.00$ invested, considering an expectation of a liveweight gain of $1 \mathrm{~kg} \mathrm{LW} \mathrm{day}{ }^{-1}$. However, the highest net income was obtained with the irrigation depth of $100 \%$ of ETo, where the benefit/cost ratio was $\mathrm{R} \$ 3.30$.

In Year 2, considering the same daily liveweight gain, the benefit/cost ratio was $R \$ 2.60$ for non-irrigated treatment (control), due to the greater water stress occurred. The benefit/cost ratio was higher for irrigated treatments from irrigation depth of $75 \%$ of ETo, while the highest value was obtained for treatment with the irrigation depth of $100 \%$ of ETo, namely $\mathrm{R} \$ 3$ 3.10. This indicator shows that productive systems with the introduction of irrigation depth with a high percentage of water supplementation are economically efficient, and maintain the economic gains stable.

The benefit/cost ratio found by Montagner et al. (2008) reinforces the results observed in this study. In the heifer rearing with millet pastures, these authors found the benefit/cost ratio ranging between $\mathrm{R} \$ 2.60$ and $\mathrm{R} \$ 3$ 3.30. Similar results was obtained by Kirchner et al. (2019b), that studied the economic viability indicators of irrigation for forage sorghum cropping for beef cattle in the region of Santa Maria-RS and obtained benefit/cost ratio of $\mathrm{R} \$ 3.16$ in 2015/2016 and $\mathrm{R} \$ 2.41$ in 2016/2017, considering the treatment with irrigation depth of $100 \%$ of ETo and expected liveweight gain of $1.0 \mathrm{~kg} \mathrm{LW} \mathrm{day}{ }^{-1}$ in both years.

\section{Conclusion}

Conventional sprinkler irrigation for the sudan grass cultivation for beef cattle production is economically viable. Irrigation is an important alternative to intensify and stabilize production over the years, and significantly increase the net revenue of the livestock activity. Although the viability is dependent on the rainfall volume and distribution, irrigation provides great benefits, mainly in drought years and/or in years with irregular rainfall distribution, and provides stable production over the years.

The economic viability of irrigation for beef cattle is also dependent of the feed conversion efficiency of grazing animals because this factor represented the highest source of net revenue variation, followed by the rainfall distribution during the crop growing period.

The sudan grass water demand must be fully supplied by irrigation, even with costs increasing, because the increase in forage production provided by the full irrigation supply leads to greater net revenue.

\section{Acknowledgement}

We the thank Coordination of Improvement of Higher Education Personnel (CAPES) and the National Council for Scientific and Technological Development (CNPq) for the financial support in the stipend and fellowship study, and to the Federal University of Santa Maria, for the study area and infrastructure. 


\section{References}

Allen, R. G., Pereira, L. S., Raes, D., \& Smith, J. (2006). Evapotranspiration del cultivo: guias para la determinación de los requerimientos de agua de los cultivos. Roma: FAO (Estudio Riego e Drenaje Paper, 56).

Almeida, V., Alves Júnior, J., Mesquita, M., Evangelista, A. W. P., Casaroli, D., \& Battisti, R. (2018). Comparação da viabilidade econômica da agricultura irrigada por pivô central em sistemas de plantios convencional e direto com soja, milho e tomate industrial. Global Science and Technology, 11(2), 256-273.

Associação Brasileira de Indústrias Exportadoras de Carne - ABIEC. (2019). Perfil da Pecuária no Brasil Relatório Anual. http://www.abiec.com.br/controle/uploads/arquivos/sumario2019portugues.pdf

Ayas, S., Orta, H., \& Yazgan, S. (2011). Deficit irrigation effects on broccoli (Brassica oleracea var. Monet) yield in unheated greenhouse condition. Bulgarian Journal of Agricultural Science, 17(4), 551-559.

Barbosa, M. A. G. (2015). Viabilidade de investimento e análise de risco econômico em projetos de irrigação para produção de tomate no agropolo Ibicoara-Mucugê, Bahia. Tese de doutorado, Universidade Federal do Recôncavo da Bahia, Cruz das Almas, BA, Brasil. http://www.repositorio.ufrb.edu.br/bitstream/123456789/925/1/MURILLO\%20ANDERSON \%20GON\%C3\%87ALVES\%20BARBOSA\%20-\%20TESE.pdf

Bernardo, S., Soares, A. A., \& Mantovani, E. C. (2008). Manual de irrigação. Viçosa, SP: Ed. UFV.

Biscaro, G. A. Sistemas de irrigação por aspersão. (2009) Dourados, MS: Ed. UFGD.

Castro Júnior, W. L., Oliveira, R. A., Silveira, S. F. R., \& Andrade Júnior, A. S. (2015). Viabilidade econômica de tecnologias de manejo da irrigação na produção do feijão-caupi, na região dos Cocais - MA. Revista Engenharia Agrícola, 35(3), 406-418. https://doi.org/10.1590/1809-4430-Eng.Agríc.v35n3p406-418/2015

Comissão de Química e Fertilidade do Solo - CQFS RS/SC. (2016). Manual de adubação e calagem para os Estados do Rio Grande do Sul e de Santa Catarina. 11. ed. Porto Alegre: SBCS - Núcleo Regional Sul/UFRGS.

Companhia Nacional de Abastecimento - CONAB. (2010). Custos de produção agrícola: a metodologia da CONAB. Brasília: CONAB.

Diavão, J., Schmitt, D., Medeiros-Neto, C., Martins, C. D. M., \& Sbrissia, A. F. (2017). Acúmulo de forragem durante o período de ocupação dos animais em pastos sob lotação intermitente. Revista ciência animal brasileira, 18, 1-11, e-41359. https://doi.org/10.1590/1809-6891v18e-41359

Empresa Brasileira de Pesquisa Agropecuária - EMBRAPA. (2011). Manual de métodos de análise de solos. (2a ed.) Rio de Janeiro, RJ: Embrapa Solos. 
Empresa Brasileira de Pesquisa Agropecuária - EMBRAPA. (2014). Revista Do Produtor. Bagé-RS.

https://www.embrapa.br/documents/1355035/2751150/revista_marco_2014.pdf/299549c8-1b 1d-4f0e-b34a-cdcc897de970

Empresa Brasileira de Pesquisa Agropecuária - EMBRAPA. (2018). Cultivar de capim-sudão - BRS-Estribo.

https://www.embrapa.br/en/busca-de-solucoes-tecnologicas/-/produto-servico/905/cultivar-de -capim-sudao---brs-estribo

Ferreira, E., Cavalcanti, P. E., \& Nogueira, D. (2014). ExpDes: An R Package for ANOVA and Experimental Designs. Applied Mathematics, 5, 2952-2958. https://doi.org/10.4236/am.2014.519280

Frizzone, J. A., \& Andrade Júnior, A. S. (2005). Planejamento da irrigação: Análise de decisão de investimento. Brasília, DF: Embrapa Informação Tecnológica.

Glienke, C. L. (2012). Estudo da recria de novilhas em corte em pastagens cultivadas de verão. Tese de Doutorado, Universidade Federal de Santa Maria, Santa Maria, RS, Brasil. https://repositorio.ufsm.br/bitstream/handle/1/4335/GLINKE\%2c\%20CARINE\%20LISETE. pdf? sequence $=1 \&$ isAllowed $=\mathrm{y}$

Instituto Brasileiro de Geografia e Estatística - IBGE. (2017). Censo agropecuário. http://seriesestatisticas.ibge.gov.br

IUSS Working Group, 2015. WRB World reference base for soil resources 2015. World Soil Resources Reports (103). FAO, Rome.

Kirchner, J. H., Robaina, A. D., Peiter, M. X., Torres, R. R., Mezzomo, W., \& Pimenta, B. D. (2019a). Viabilidade financeira da irrigação em sorgo forrageiro em sistema de aspersão para bovinocultura de corte. Revista Irriga, https://doi.org/10.15809/irriga.2019v24n1p143-161

Kirchner, J. H., Robaina, A. D., Peiter, M. X., Torres, R. R., Mezzomo, W., \& Ben, L. H. B. (2019b). Indicadores de viabilidade econômica de produção irrigada de sorgo forrageiro para bovinocultura de corte. Revista Irriga, 24(4), 843-860. https://doi.org/10.15809/irriga.2019v24n4p843-860

Koetz, M., Bär, C. S. L. E. L., Pacheco, A. B., Castro, W. J. R., Crisostomo, W. L., \& Silva, E. M. B. (2017). Produção e eficiência no uso da água do capim paiaguás sob tensões de água no solo. Revista Brasileira de Agricultura Irrigada, 11(1), 1223-1232. doi: 10.7127/rbai.v11n100571

Lima Junior, J. A., Pereira, G. M., Geisenhoff, L. O., Silva, W. G., Souza, R. O. R. M., \& Vilas Boas, R. C. (2014). Economic viability of a drip irrigation system on carrot crop. Revista de Ciências Agrárias Amazonian Journal of Agricultural and Environmental Science, 57(1), 15-21. https://doi.org/10.4322/rca.2013.060

Marouelli, W. A., \& Silva, W. L. C. (2011). Seleção de sistemas de irrigação para hortaliças. 
2. ed. Circular Técnica 11. Brasília: Embrapa Hortaliças, 20 p.

Mendonça, F. C., Camargo, A. C., Stivari, A., Lima, C. R. C., Ferreira, F. C., Akinaga, L., ... Neto, P. Q. (2007). Dimensionamento de sistemas de irrigação para pastagens em propriedades de agricultura familiar. Boletim de Pesquisa e Desenvolvimento / EMBRAPA Pecuária Sudeste, 10.

Millar, A. A. (1978). Drenagem de terras agrícolas: bases agronômicas. São Paulo, SP: McGraw-Hill do Brasil, LTDA.

Montagner, D. B., Rocha, M. G., Santos, D. T., Genro, T. C. M., Quadros, F. L. F., Roman, J., Potter, L., \& Bremm, C. (2008). Manejo da pastagem de milheto para recria novilhas de corte. Ciência Rural, 38(8), 2293-2299. https://doi.org/10.1590/S0103-84782008000800031.

Paredes, P., Rodrigues, G. C., Alves, I., \& Pereira, L. S. (2014). Partitioning evapotranspiration, yield prediction and economic returns of maize under various irrigation management strategies. Agricultural Water Management, 135(1), 27-39. https://doi.org/10.1016/j.agwat.2013.12.010

Pereira, R. M., Alves Júnior, J., Casaroli, D., Sales, D. L., Rodriguez, W. D. M., \& Souza, J. M. F. (2015). Viabilidade econômica da irrigação de cana-de-açúcar no cerrado brasileiro. Revista Irriga, Edição Especial, IRRIGA \& INOVAGRI, 1(2), 149-157. https://doi.org/10.15809/irriga.2015v1n2p149

$\mathrm{R}$ Core Team (2018). R: A language and environment for statistical computing. R Foundation for Statistical Computing, Vienna, Austria. https://www.R-project.org/

Reis, M. M., Santos, L. D. T., Oliveira, F. G., \& Santos, M. V. (2017). Irrigação de pastagens tropicais: desafios e perspectivas. Revista Unimontes Cientifica, Montes Claros, 19(1), 178-190.

Santos Júnior, J. L. C., Frizzone, J. A., \& Paz, V. P. S. (2014). Otimização do uso da água no perímetro irrigado formoso aplicando lâminas máximas de água. Revista Irriga, 19(2), 196-206. https://doi.org/10.15809/irriga.2014v19n2p196

Santos, H. G., Jacomine, P. K. T., Anjos, L. H. C., Oliveira, V. A., Lumbreras, J. F., Coelho, M. R., ... Cunha, T. J. F. (2018). Sistema brasileiro de classificação de solos. 5. ed. rev. e ampl. Brasília, DF: EMBRAPA. 356 p.

Silva, F. A., Freitas, F. C. L., Rocha, P. R. R., Cunha, J. L. X. L., Dombroski, J. L. D., Coelho, M. E. H., \& Lima, M. F. P. (2015). Milho para ensilagem cultivado nos sistemas de plantio direto e convencional sob efeito de veranico. Semina: Ciências Agrárias, 36(1), 327-340. https://doi.org/10.5433/1679-0359.2015v36n1p327

Silva, W. G., Carvalho, J. A., Oliveira, E. C., Lima Junior, J. A., \& Silva, B. M. (2013). Technical and economic analysis of irrigation of asparagus bean in protected environment. Revista Engenharia Agrícola, 33(4), 658-688. https://doi.org/10.1590/S0100-69162013000400007 
Silveira, M. C. T., Sant'Anna, D. M., Montardo, D. P., \& Trentin, G. (2015). Aspectos relativos à implantação e manejo de capim sudão BRS Estribo. EMBRAPA. Comunicado Técnico 89, Bagé-RS.

https://ainfo.cnptia.embrapa.br/digital/bitstream/item/135361/1/COT89online.pdf

Soares, J. C. R., Barcellos, J. O. J., Queiroz Filho L. A. V., Oaigen, M. E. A., Canozzi, C. M., Drumond, L. C. D., \& Braccini Neto, J. (2015). Avaliação econômica da terminação de bovinos de corte em pastagem irrigada. Arq. Bras. Med. Vet. Zootec., 67(4), 1096-1104. https://doi.org/10.1590/1678-4162-7340

Torres, R. R., Robaina, A. D., Peiter, M. X., Ben, L. H. B., Mezzomo, W., Kirchner, J. H., ... Girardi, L. B. (2019). Economic of the irrigated production of forage millet. Semina: Ciências Agrárias, 40(2), 623-638. https://doi.org/10.5433/1679-0359.2019v40n2p623

Trindade, Junior. G., Silva, R. R., Carvalho, G. G. P., Silva, F. F., Negrão, J. A., Barroso, D. S., ... Costa, P. B. (2015). Compensatory gain of crossbred heifers supplemented in pastures under evaluation hormonal profile and blood parameters. Semina: Ciências Agrárias, 36(3), 1481-1494. https://doi.org/10.5433/1679-0359.2015v36n3p1481

Wollmann, C. A., \& Galvani, E. (2012). Caracterização climática regional do Rio Grande do Sul: dos estudos estáticos ao entendimento da gênese. Revista Brasileira de Climatologia, 11(8), 87-103. https://doi.org/10.5380/abclima.v11i0.28586

Zhang, G., Liu, C., Xiao, C, Xie, R., Ming, B., Hou, P., ... Li, S. (2017). Optimizing water use efficiency and economic return of super high yield spring maize under drip irrigation and plastic mulching in arid areas of china. Field Crops Research, 211(1), 137-146. https://doi.org/10.1016/j.fcr.2017.05.026

\section{Copyright Disclaimer}

Copyright for this article is retained by the author(s), with first publication rights granted to the journal.

This is an open-access article distributed under the terms and conditions of the Creative Commons Attribution license (http://creativecommons.org/licenses/by/4.0/). 